\title{
Review of U.S. Apparel and Textile Imports From China and Three Other Regions, 1995-2006
}

\author{
Shu-Hwa Lin \\ University of Hawai'i at Mānoa, Mānoa, United States
}

\begin{abstract}
This project is to evaluate the benefits of the MFN status and the consequences of non-MFN renewal on trades between China and the United States. This paper also reveals the effects of quota removal on clothing and textile products on international trades between the United States, China, Hong Kong, Taiwan, and India. Data analyses, statistics, and charts, the changes in China's number of exports to the United States, in particular, the apparel and textile sectors were selected to analyze from 1995 to 2005 .
\end{abstract}

Keywords: apparel import, textile import, US apparel \& Textile, MFN

\section{Introduction}

In the early 1900s, China's economy developed at a relatively slow pace because of stagnant governmental policies, which controlled trade prices and productions. The economic reforms in 1979 marked the blooming of the Chinese trade. The Chinese government established four special economic zones along the coast to attract foreign investments, boost exports, and import technological products into China. Price controls on a variety of products were eventually eliminated over time. With such reforms in place, China quickly became one of the world's fastest-growing economies. There are two major factors, which have contributed to China's rapid economic growth after the reforms. The first was the increase in large-scale capital investment by foreign companies in China. The second was the escalation of productivity primarily by reallocating resources for appropriate uses, especially in the agriculture, trade, and service sectors. As a result, China's foreign trades (exports and imports) also grew significantly in a short matter of time. It eventually became one of the primary countries to export heavy labor goods to the United States (Morrison, 2006).

After the increase in trades in 1980, China was regarded as the United States' most favored nation (MFN). The recognition of MFN status allowed China to receive low duty rates for exports to the United States. MFN rates were determined through multilateral trade negotiations with the World Trade Organizations (Arce \& Taylor, 1997). With MFN, China enjoyed low tariffs that averaged to 5.2 percent. Prior to the full MFN status, China was subjected to the Column 2 duty rates, which averaged to a 44.49 percent tariff. Each year, China had to renew its MFN status with the United States. Issues of emigration and human rights became the basis of consideration for determining whether China's MFN status renewal would be accepted by the United States (Yao, 2000).

Shu-Hwa Lin, Ph.D., Department of Family \& Consumer Sciences, University of Hawai'i at Mānoa, Mānoa, United States.

Correspondence concerning this article should be addressed to Dr. Shu-Hwa Lin, 2515 Campus Rd., Miller Hall 201, Honolulu HI 96822, United States. 


\section{Objectives}

The objective of this paper is to evaluate the benefits of the MFN status and the consequences of non-MFN renewal on trades between China and the United States. This paper also reveals the effects of quota removal on clothing and textile products on international trades between the United States, China, Hong Kong, Taiwan, and India. Through written analyses, statistics, and charts, the changes in China's number of exports to the United States, in particular, the apparel and textile sectors, prior and following the elimination of quotas, are shown.

\section{Literature Review}

\section{China's MFN Status}

Since China was entitled the MFN by the United States, the country quickly became a major trading partner of the United States. The United States found favor in trading with China due to its abundance of cheap labor. A substantial amount of China's imports from the United States contained parts and components to be assembled in Chinese factories, and then exported back to the United States. Aside from parts and components, raw materials and production machineries such as cotton and textile-production machinery, also occupied large shares of China's imports because they were essential elements to produce textile and apparel items for exports (Yao, 2000).

From the beginning of China's economic reforms in 1979 until 2005, the country's imports grew from $\$ 16$ billion to $\$ 660$ billion. Its exports rose even more significantly from $\$ 14$ billion to $\$ 762$ billion over the course of 26 years. The size of China's overall economy in 2005 was $17 \%$ higher than previously estimated (Morrison, 2006). The success of China's trade since its reforms owed greatly to its geographic location and linkage to Hong Kong. For a long period, Hong Kong handled 75 percent of the United States-China trade and collaborated with mainland China in exporting textile and clothing to the United States (Yao, 2000).

China's economic growth presented numerous opportunities for U.S. importers. Importers were able to attain massive amounts of products at a cheap price to be sold in businesses within the United States. The demand on high-tech exports to China from the United States also increased. At the same time, the amount of Chinese exports to the United States continued to add pressure on many domestic U.S. industries and deemed harmful to the United States' long-term economic interests. With cheap and abundant labor in China, many U.S. manufactures struggled to compete with the many low-cost and labor-intensive factories (Morrison, 2006).

With foreseeable economic harms to the United States, annual debates occurred to discuss whether it would be feasible to renew and grant China's Most Favored Nation status in trading. Even more so, after the Cold War in 1989, debates expanded from economic issues to political agendas in China. The issues of China's human rights, weapon proliferation, campaign contributions, and nuclear espionage have became serious concerns in renewing the country's MFN status (Yao, 2000).

Despite China's cheap labor and high productivity, the quality of China's consumer imports to the United States was also questioned. Goods from China were not been subjected to the same regulations and inspections as those produced in the United States, making the quality and safety of products very uncertain. Since 1997, the volume of consumer goods from China tripled, heightening the risk of selling dangerous products. Greater than 40 percent of recalls by the United States Consumer Product Safety Commission were related to products from China. Yet, in spite of the significant amount of trades between the two countries, the United States 
government had little power to impose new restrictions on Chinese goods. Many businesses in the U.S. market have been testing imports from Chinese companies for years, and this kind of constant monitoring is not cheap. Nancy Nord, suggest that rather have the products manufactured safely in the first place, explained acting Consumer Product Safety Commission chairperson. The real test to China's long-term economic wellbeing depends not on its ability to or system of mass produce, but whether its Chinese imports will receive the same assurance of safety and products produced locally in the United States (Thottam, Elegant, Kingsbury, Ramzy, \& Weisskopf, 2007).

As the MFN trading privileges were granted to other countries as major trading partners, the term Most Favored Nation was replaced with the title Normal Trade Relations in 1998. This new title appeared to be more appropriate in describing the trade status between China and the United States. The Normal Trade Relations status later became one of the underlying principles and requirements between trading partners of the World Trade Organization under the General Agreement on Tariffs and Trade (GATT). This agreement ensured the equal and nondiscriminatory application of tariffs on all World Trade Organization members, including China (Yao, 2000).

Major studies were done by World Bank to simulate the consequences of discontinuing China's Normal Trade Relations status from the United States. The removal of NTR status was assumed to affect China's trade and industrial output. Increases in the tariff on textiles and wearing apparel were estimated to 42 and 55 percent, respectively. This substantial increase could lead to a significant drop in the import of textiles and wearing apparel to the United States below the quota level. Overall, China could lose 42 to 96 percent of its total exports to the United States, with the wearing apparel sector decreasing up to 90 percent (Arce \& Taylor, 1997). While this removal would result in the disintegration between the United States and China's economies, it would promote integration of the Chinese trade sector with other high-tech sectors, including Japan and EU. However, the demand for goods in Japan and EU could be lower than the United States (Yao, 2000).

The United States would also be impacted negatively by a decrease in imports from China and an increase in import prices from other nations. The total imports from China to the United States were estimated to drop by $\$ 11$ billion, slightly over 50 percent. Overtime, other regions of the world would replace a significant amount of China's exports to the United States through trades. However, these regions would not be able to compare to China in terms of price and productivity. This would affect the production costs of goods, which in turn would heighten the domestic price of products sold in the United States. Even with the substitute of imports from other countries, the United States' overall imports would decrease by $\$ 4.5$ billion. Both countries, China and the United States, would lose in terms of real income (Arce \& Taylor, 1997). The end winners of this conflict between China and the United States would be Japan, EU, and other runner-up countries (Yao, 2000).

In 2000, the question of granting China's permanent normal trade relations status became a serious debate in the United States Congress. Many Congressmen opposed the idea of granting China's permanent status until the country fully opens its markets and stops suppressing its workers. Meanwhile, those in the farming and business sectors continued to push for the passage of the permanent status, which would give them expandable resources to the Chinese markets (China Trade, 2000).

At last, Congressional representatives agreed that the entry into the Chinese markets might be essential to maintain the vitality of the U.S. economy for the time being. Furthermore, it has been a principle of the United States for over 20 years to promote free foreign trade. Thus, most felt that this principle was not to be contested. Aside from this reason, the Congress also wanted to take the Chinese cooperation seriously, as they seemed 
essential for the safeguard of peaceful international relations. With these factors being considered, the bill giving China its permanent normal trade rights was passed by 237 against 197 votes (China Trade, 2000).

Opponents of the bills revealed that they were not in opposition to trading with China. However, they felt that it was not an appropriate action to make China's trade status permanent at that moment. The yearly renewal of China's status for the past 10 years allowed for an annual Congressional review to raise questions on Beijing's suppression of human rights. The renewal also provided the United States with some authority and influence on diminishing China's human right abuses. With this bill approving China's permanent trading status, China's human rights became the primary concern for many. However, in favor of the bill, President Clinton at the time expressed that free trade could democratize China and hopefully bolster freedom. Although he later admitted that trade alone could not bring freedom to China or peace to the world (China Trade, 2000).

To alleviate harms to China's human rights with this new privilege and status given to China, the United States set up an amendment along with the passing of the bill. Through this amendment, a 23-member commission was formed to monitor human rights issues in China. The amendment also established limits in regards to China's trades with the United States for the first 10 years after the bill was passed (China Trade, 2000).

\section{Trades on Textile and Apparel}

While international trades in China were expanding, China's textile and wearing apparel exports did not grow exponentially because of the Multi-fiber Arrangement (MFA) quota set by the Chinese government in 1974 on the amount of exporting goods in these two sectors. The MFA was signed and conceived as a temporary arrangement to progressively advance the quota-free trade for textile and clothing. After 20 years, however, there were only gradual reductions of trade barriers in China under the MFA (Martin, 2007).

In 1995, the Agreement on Textiles and Clothing (ATC) was signed to replace the MFA. The ATC started a 10-year long process in eliminating the set quota for international trade in the textile and clothing sectors. This process was completed in four stages; products from the textiles and clothing, wool, cotton, and synthetic fiber categories were given an increased quota at each of the four phases (Martin, 2007).

Table 1

Quota Phase-out Mechanisms of the ATC

\begin{tabular}{lll}
\hline Date & $\begin{array}{l}\text { Accumulated share of clothing and textile trade without } \\
\text { quotas }\end{array}$ & $\begin{array}{l}\text { Increase in size of quota for clothing and textile trade still } \\
\text { subject to quotas }\end{array}$ \\
\hline $1 / 1 / 1995$ & $16 \%$ & $16 \%$ \\
$1 / 1 / 1998$ & $33 \%$ & $25 \%$ \\
$1 / 1 / 2002$ & $51 \%$ & $27 \%$ \\
$1 / 1 / 2005$ & $100 \%$ & Full integration \\
\hline
\end{tabular}

Source: CRS Report for Congress, 2007.

The elimination of quotas was expected to foster a growth in clothing and textile trade and to restructure the clothing and textile manufactures for increased production. The end of the ATC quota was also predicted to bring three major changes to the U.S. market. First, there would be a drastic increase in U.S. clothing and textile imports. Second, business owners in the U.S. would shift their clothing and textile imports from other countries to China due to the country's cheap labor and sharp price drops with the elimination of quotas. Clothing and textiles imports would consume from one-third to two-thirds of the United States' overall imports. 
Third, the influx of clothing and textile imports was expected to cause the downsizing of the clothing and textile industry in domestic U.S., which would ultimately result in loss of employments up to 630,000 jobs. The severity of loses could possibly trigger the United States and other WTO members to impose trade remedies in response to the increasing imports from China (The American Textile Manufacturers Institute, 2002).

Table 2

Projected Textile \& Apparel Job Losses

\begin{tabular}{ll}
\hline State & Job losses \\
\hline North Carolina & 85,000 \\
California & 81,000 \\
South Carolina & 42,000 \\
Alabama & 30,000 \\
New York & 29,000 \\
Georgia & 25,000 \\
Total all states & 630,000 \\
\hline
\end{tabular}

Source: The American Textile Manufacturers Institute, 2002.

On January 1, 2005, the last set of quotas under ATC was eliminated for WTO members. Post ATC, the United States imposed safeguard measures and ensured a smooth transition by continuing the quotas for 10 different clothing and textile categories until 2008. Under this safeguard quota, the rate of increase between the United States and China was set to 10 percent in 2006, 12.5 percent in 2007, and 15 percent in 2008. The United States also expressed the possibility of imposing additional safeguarding actions if this unlimited trade proved to be disruptive to the clothing and textile markets in the United States. China further allowed other WTO members to utilize two safeguard mechanisms against Chinese clothing and textile products if the importing country believes that the Chinese imports are causing or threatening to cause domestic market disruption. This safeguard measure can be invoked by any WTO member and is effective until December 10, 2013. For instance, United States could raise its import tariffs to keep foreign companies from controlling the nation's clothing and textile market, and thus, protecting its domestic markets. Although these protective measures may seem to work positively in protecting each nation's wellbeing in radical situations, they also destroyed the idea of absolute free trade (Martin, 2007).

In actuality, during the 10-year duration of ATC, the United States did become a major importer in clothing and textiles, investing in over $\$ 80$ billion in clothing and $\$ 23$ billion in textile imports. The average price of clothing and textile declined from $\$ 6.23$ to $\$ 3.37$ per square meter, approximately 46 percent. Thus, between 1990 and 2006, clothing imports to the United States raised $\$ 59$ billion, averaging an annual growth of 14.2 percent. Textiles, although not as drastic of an increase as clothing, raised $\$ 7.3$ billion as well, averaging to an annual growth of $7.6 \%$. China and India expanded their exports in these two sectors and captured nearly 85 percent of the increased demands. From 2004 to 2005, China's clothing exports alone raised $\$ 12.3$ billion, 19.9 percent. In 2006, the top five sources of U.S. clothing imports were China, Mexico, India, Indonesia, and Bangladesh, respectively. That same year, the top five sources of U.S. textile imports were China, Canada, India, South Korea, and Mexico. Hong Kong, which was ranked as one five major exporters to the United States, dropped to rank six (Martin, 2007). 
Table 3

Ten Safeguard Quota Utilization Rates

\begin{tabular}{lll}
\hline Category & Quota limit & Utilization rate \\
\hline Combed cotton yarn & $1,450,777 \mathrm{~kg}$ & $72 \%$ \\
Hosiery & $10,298,023$ dozen pair & $100 \%$ \\
Cotton knitted shirts \& blouses & $4,704,115$ dozen & $100 \%$ \\
Men's \& boys' woven shirts & $2,213,126$ dozen & $100 \%$ \\
Cotton trousers & $4,340,638$ dozen & $100 \%$ \\
Brassiere \& support garments & $7,275,216$ dozen & $71.50 \%$ \\
Underwear & $5,062,892$ dozen & $100 \%$ \\
Other synthetic filament fabric & $12,328,306$ sq. m. & $100 \%$ \\
Man-made fiber knitted shirts \& blouses & $2,844,383$ dozen & $100 \%$ \\
Man-made fiber trousers, breeches \& shorts & $2,660,678$ dozen & $100 \%$ \\
\hline
\end{tabular}

Source: CRS Report for Congress, 2007.

Table 4

Chinese Price Changes by Fiber in 2002

\begin{tabular}{ll}
\hline Fiber & Price drop \\
\hline Cotton & $-48 \%$ \\
Man-made fiber & $-48 \%$ \\
Vegetable fibers & $-29 \%$ \\
Wool & $-4 \%$ \\
Mixed fibers & $-57 \%$ \\
Average total price drop & $-46 \%$ \\
\hline
\end{tabular}

Source: The American Textile Manufacturers Institute, 2002.

Table 5

Top Five Clothing Suppliers to the U.S.

\begin{tabular}{llllll}
\hline Year & First & Second & Third & Fourth & Fifth \\
\hline 1995 & China & Hong Kong & Mexico & Taiwan & $\begin{array}{l}\text { South Korea } \\
\text { Dominican } \\
\text { Republic }\end{array}$ \\
1996 & China & Mexico & Hong Kong & Taiwan & Taiwan \\
1997 & China & Mexico & Hong Kong & Dominican Republic & Taiwan \\
1998 & Mexico & China & Hong Kong & Dominican Republic & Tonduras \\
1999 & Mexico & China & Hong Kong & Dominican Republic & Hond \\
2000 & Mexico & China & Hong Kong & Dominican Republic & Honduras \\
2001 & Mexico & China & Hong Kong & Honduras & India \\
2002 & China & Mexico & Hong Kong & India & Honduras \\
2003 & China & Mexico & Hong Kong & India & Honduras \\
2004 & China & Mexico & Hong Kong & India & Honduras \\
2005 & China & Mexico & India & Hong Kong & Indonesia \\
2006 & China & Mexico & India & Indonesia & Bangladesh \\
\hline
\end{tabular}

Source: CRS Report for Congress, 2007. 
Table 6

Top Five Textile Suppliers to the U.S.

\begin{tabular}{llllll}
\hline Year & First & Second & Third & Fourth & Fifth \\
\hline 1995 & Canada & South Korea & Italy & Japan & China \\
1996 & Canada & South Korea & Italy & Mexico & Taiwan \\
1997 & Canada & South Korea & Mexico & China & Italy \\
1998 & Canada & South Korea & Mexico & Italy & China \\
1999 & Canada & South Korea & Mexico & China & Taiwan \\
2000 & Canada & Mexico & South Korea & China & Italy \\
2001 & Canada & Mexico & South Korea & China & Italy \\
2002 & Canada & Mexico & South Korea & China & India \\
2003 & Canada & China & South Korea & Mexico & India \\
2004 & Canada & China & Mexico & South Korea & India \\
2005 & Canada & China & Mexico & South Korea & India \\
2006 & China & Canada & India & South Korea & Mexico \\
\hline
\end{tabular}

Source: CRS Report for Congress, 2007.

Despite the apparent increases, the growth in imports into the United States was not as dramatic as expected after the termination of the ATC quotas. The year-to-year imports of clothing and textile into the United States from 2004-2005 followed the gradual rising import trend of the previous years, not showing significant surges after the second and third phases of the ATC. In 2005, after ATC was fully eliminated, U.S. clothing imports only increased by 5.7 percent, while its textiles grew by 9.1 percent. Nevertheless, China was a major beneficiary, capturing over three quarters of the increase. In addition, this percentage of increase in exports in a year was already considered sizeable compared to the subsequent growth slowdown in 2006 (Martin, 2007).

Although the increase in imports from China was not as radical as anticipated, it did cause sizeable downsizing for U.S. manufacturers. A steady downward trend was observed in domestic clothing and textile employment even prior to the full establishment of ATC. Some U.S. manufacturers even went the full extend to cite quality concerns in the imports from China to urge the United States government to establish additional safeguard measures in mitigating devastating closures. The increased competition was resulted from the growth in imports, as well as the economical price of products from China. This often pressured domestic manufacturers in the United States to lower their prices. In 2007, the Trade Adjustment Assistance Act of 1974 was reintroduced by the Congress, which lowered the qualifications of clothing and textile workers to become eligible for federal funding and other financial assistance (Martin, 2007).

\section{China After Trade Quota Removal}

Although China obtained its permanent Normal Trade Relations status and abolished its trade quotas, the country continues to face major long-term challenges that could seriously affect its economy and trade businesses in the future. Up to year 2006, a third of China's industrial productions were state-owned enterprises. A majority of them were not profitable. Thus, the Chinese government's support of unprofitable state-owned enterprises actually diverted resources away from many potential enterprises that could be more efficient and profitable. The poor financial condition of the state-owned enterprises also made the Chinese government reluctant to lessen the trade barriers in fear that this may lead up to widespread bankruptcies. The banking system in China is often corrupted. Most banks, which are regulated and controlled by the central government, 
were pressured to offer low interest loans to support the state-owned enterprises. Statistics in 2006 showed that approximately $50 \%$ of loans went to the state-owned enterprises. Instead of operating on market-based principles, China's banking system has been corrupted with political connections (Morrison, 2006).

In addition to the widespread governmental corruption and the misallocation of investment funds, China had caused public unrests over issues of pollution and income inequality. Pollution continues to pose major health risks to the population in China even today. Yet, the Chinese government often disregarded the public health by placing emphasis on rapid economic growth rather than the environmental laws. The increasing income inequality between the Chinese living in the urban coastal areas and those in the inner rural regions resulted in serious tensions. Those not benefitting from China's rapid economic reforms and growths were overlooked, and thus, became poorer overtime. The rich, on the other hand, got richer due to governmental connections. These problems, which persist today, surfaced China's non-consistent and non-transparent rules and regulations, lack of contract enforcements and unprotected property rights. They also made many U.S. firms reluctant to conduct businesses in China. To promote further advancements in China's economy, these problems must be corrected within China's own system of conducting businesses and trades (Morrison, 2006).

Despite the severe problems that exist within China, the country's short-term economy is positive, especially after being granted the permanent favorable trade status. With the desire to become a world leader in the production business, the Chinese government attempts to establish larger corporations that can compete globally and to take over major international corporations. Meanwhile, disruptions to the United States' economy and trade businesses would also cause damage to the Chinese economy since over one-third of China's exports go to the United States (Morrison, 2006).

\section{Methods}

This report is composed from a collection of written analyses, which effectively described changes that took place in world trades between China and the United States before and after the granting of China's permanent Normal Trade Relations status. Aside from literary references, the theoretical RCA model was adopted by the U.S. Department of Commerce in collecting numerical data to evaluate the effects of clothing and textile international imports between the United States and its major partners, including China, Hong Kong, Taiwan, and India. Data calculated using the RCA model were retrieved through the U.S. International Trade Administration's online data bank. The data obtained between years 1989-2008 were organized into charts and graphs using the Microsoft Office software, and is shown in this report.

The following categories of clothing and textile trades are used to illustrate the implications on future trades:

- SITC 8411: Overcoats, car coats, capes, anoraks (Including ski-jackets), etc. (Except suit-type jackets and blazers) of woven fabrics, men's or boys';

- SITC 8412: Suits and ensembles of woven textile materials, men's or boys';

- SITC 8413: Jackets (suit-type) and blazers of woven textile materials, men's or boys';

- SITC 8414: Trousers, bib and brace overalls, breeches and shorts of woven textile materials, men's or boys';

- SITC 8415: shirts of woven textile materials, men's or boys';

- SITC 8416: Singlets (undershirts), underpants, briefs, nightshirts, pajamas, bathrobes, and similar articles of woven textile materials, men's or boys'; 
- SITC 8421: Overcoats, car coats, capes, anoraks (Including ski-jackets), etc. (Except suit-type jackets and blazers) of woven fabrics, women's or girls';

- SITC 8422: Suits and ensembles of woven textile fabrics, women's or girls';

- SITC 8423: Jackets and blazers, women's and girls', not knitted or crocheted;

- SITC 8424: Dresses of woven textile fabrics, women's or girls';

- SITC 8425: Skirts and divided skirts of woven textile fabrics, women's or girls';

- SITC 8426: Trousers, bib and brace overalls, breeches and shorts, of woven textile fabrics, women's or girls';

- SITC 8427: Blouses, shirts and shirt-blouses of woven textile fabrics, women's or girls'.

\section{Results and Discussion}

The data shown through Tables 7-19 illustrated the amount of imports from China, Hong Kong, Taiwan, and India to the United States over the course of 19 years. These figures revealed the actual impact of the elimination of quota on clothing and textile imports. For China, all of its imports to the United States (SITC $8411,8412,8413,8414,8415,8416,8421,8422,8423,8424,8425,8426)$ were not significantly affected by the elimination of quota. In fact, during the 10-year duration of ATC, it appeared that China's overall number of imports to the United States dropped at a gradual, but relatively constant rate. This is a rather interesting result considering that China continued to expand its trade affairs through the years. In 2005, at the final elimination of ATC, there was an increase in imports shown through the data. However, this increase was not as dramatic as expected. In fact, the years following 2006 showed a slight decline of imports for over half of the clothing and textile products.

Imports from Hong Kong showed huge fluctuations between 1989 and 2008. The peak period of imports to the United States (for SITC 8412, 8413, 8416, 8422, 8425) appeared to be in 1995 prior to the enactment of the ATC. After the passing of ATC, as larger nations gradually took control of a majority of imports to the United States, the imports from Hong Kong dropped severely. For other clothing and textile products (SITC $8411,8414,8415,8421,8423,8426,8427)$, imports did increase in correspondence to the elimination phases of the ATC. Imports for these products escalated to their maximum in 2005 after the final quota of ATC was removed. However, in the following year, all imports from Hong Kong began to decline, some gradually, others drastically.

The imports from Taiwan to the United States remained relatively constant through the years. There were slight variations in the quantity of imports, but the country did not seem to be affected by the quota control in clothing and textile. This is partially because Taiwan was never a major importer of clothing and textile products to the United States. Thus, the quota limit did not restrict the amount of imports. In the same sense, the removal of the quota did not increase the imports from Taiwan as well.

India showed great variations in its amount of imports to the United States. Imports grew for some of the country's clothing and textile products (SITC 8411, 8413, 8414, 8421, 8423, 8427), parallel to the expected increase during the ATC phase-out period. However, the needs for these products dropped immediately following year 2005. For several other products (SITC 8412, 8415, 8416, 8425, 8426), the number of imports stayed relatively constant through the years, with only slight variants. Yet, for two clothing and textile categories (SITC 8422, 8424), imports started to decrease around year 1995, and continued to decline through year 2008 . 
Table 7

SITC 8411 Imports

\begin{tabular}{lllll}
\hline & China & Hong Kong & Taiwan & India \\
\hline 1989 & 14.90 & 12.21 & 6.60 & 1.40 \\
1990 & 13.20 & 14.81 & 6.20 & 1.70 \\
1991 & 10.75 & 14.02 & 5.87 & 3.10 \\
1992 & 9.90 & 14.46 & 4.60 & 3.79 \\
1993 & 8.70 & 15.94 & 4.97 & 4.77 \\
1994 & 7.13 & 18.69 & 6.28 & 4.68 \\
1995 & 8.15 & 16.19 & 5.72 & 4.10 \\
1996 & 8.04 & 17.40 & 5.74 & 3.84 \\
1997 & 7.76 & 15.30 & 5.73 & 4.46 \\
1998 & 6.35 & 20.65 & 5.89 & 5.09 \\
1999 & 6.81 & 21.02 & 4.92 & 5.66 \\
2000 & 6.69 & 21.04 & 5.12 & 8.73 \\
2001 & 6.53 & 19.98 & 4.83 & 7.20 \\
2002 & 5.80 & 20.32 & 4.02 & 7.78 \\
2003 & 5.34 & 20.16 & 4.10 & 9.93 \\
2004 & 5.04 & 16.06 & 3.84 & 5.49 \\
2005 & 5.86 & 3.54 & 1.79 & 3.33 \\
2006 & 5.84 & 1.74 & 0.96 & 2.80
\end{tabular}

Source: U.S. Department of Commerce, International Trade Administration, 1989-2008.

Table 8

SITC 8412 Imports

\begin{tabular}{lllll}
\hline & China & Hong Kong & Taiwan & India \\
\hline 1989 & 16.12 & 278.29 & 5.02 & 3.26 \\
1990 & 13.62 & 375.11 & 5.60 & 3.21 \\
1991 & 10.55 & 409.67 & 4.62 & 0.08 \\
1992 & 11.04 & 394.08 & 3.03 & 0.03 \\
1993 & 10.48 & 401.37 & 3.06 & 0.05 \\
1994 & 9.23 & 547.86 & 4.49 & 0.07 \\
1995 & 8.81 & 638.06 & 5.31 & 0.57 \\
1996 & 8.26 & 18.39 & 5.31 & 2.73 \\
1997 & 7.83 & 14.65 & 5.31 & 5.99 \\
1998 & 6.49 & 16.18 & 4.29 & 22.29 \\
1999 & 5.91 & 16.25 & 3.96 & 27.68 \\
2000 & 5.11 & 15.83 & 4.69 & 30.66 \\
2001 & 4.81 & 19.07 & 4.03 & 28.09 \\
2002 & 4.50 & 18.00 & 2.14 & 33.37 \\
2003 & 3.63 & 16.75 & 2.81 & 33.68 \\
2004 & 3.23 & 19.31 & 2.71 & 9.13 \\
2005 & 5.56 & 9.70 & 0.38 & 6.94 \\
2006 & 5.37 & 11.27 & 0.50 & 7.76 \\
2007 & 4.99 & 13.69 & 0.15 & 6.90 \\
2008 & 5.25 & 14.22 & 0.10 & \\
\hline
\end{tabular}

Source: U.S. Department of Commerce, International Trade Administration, 1989-2008. 
Table 9

SITC 8413 Imports

\begin{tabular}{lllll}
\hline & China & Hong Kong & Taiwan & India \\
\hline 1989 & 14.35 & 16.80 & 5.02 & 3.11 \\
1990 & 11.83 & 20.10 & 5.73 & 4.50 \\
1991 & 10.45 & 16.97 & 3.83 & 4.04 \\
1992 & 11.94 & 14.83 & 2.83 & 0.41 \\
1993 & 10.70 & 25.39 & 2.96 & 0.37 \\
1994 & 10.67 & 42.69 & 2.68 & 0.89 \\
1995 & 10.42 & 33.45 & 1.80 & 1.60 \\
1996 & 11.12 & 13.85 & 2.33 & 0.21 \\
1997 & 10.30 & 9.09 & 1.84 & 7.84 \\
1998 & 9.42 & 7.71 & 3.10 & 5.16 \\
1999 & 9.06 & 10.39 & 3.17 & 3.21 \\
2000 & 8.62 & 12.81 & 2.89 & 4.31 \\
2001 & 7.82 & 9.82 & 1.04 & 17.70 \\
2002 & 6.90 & 8.28 & 0.62 & 13.96 \\
2003 & 6.52 & 5.73 & 1.29 & 10.27 \\
2004 & 5.42 & 7.48 & 1.70 & 14.80 \\
2005 & 5.26 & 4.36 & 0.49 & 15.30 \\
2006 & 5.36 & 1.92 & 0.01 & 11.22 \\
2007 & 5.20 & 1.80 & 0.06 & 8.61 \\
\hline 508 & 5.30 & 2.50 & 0.02 & 9.25 \\
\hline
\end{tabular}

Source: U.S. Department of Commerce, International Trade Administration, 1989-2008.

Table 10

SITC 8414 Imports

\begin{tabular}{lllll}
\hline & China & Hong Kong & Taiwan & India \\
\hline 1989 & 11.51 & 2.24 & 5.81 & 1.51 \\
1990 & 11.13 & 1.68 & 5.60 & 2.40 \\
1991 & 8.90 & 1.50 & 4.96 & 3.04 \\
1992 & 8.08 & 1.43 & 4.07 & 2.96 \\
1993 & 8.09 & 1.59 & 3.79 & 2.06 \\
1994 & 7.34 & 1.46 & 3.59 & 1.98 \\
1995 & 7.27 & 0.93 & 3.30 & 3.69 \\
1996 & 6.42 & 31.50 & 3.82 & 3.54 \\
1997 & 6.20 & 31.47 & 3.71 & 5.48 \\
1998 & 5.33 & 34.31 & 3.55 & 6.23 \\
1999 & 5.42 & 36.44 & 3.36 & 8.46 \\
2000 & 4.97 & 39.19 & 3.62 & 14.35 \\
2001 & 4.46 & 40.84 & 3.67 & 13.74 \\
2002 & 3.83 & 43.60 & 2.72 & 11.85 \\
2003 & 3.96 & 43.36 & 2.75 & 13.01 \\
2004 & 3.79 & 43.44 & 2.32 & 13.52 \\
2005 & 4.18 & 35.13 & 1.33 & 15.36 \\
2006 & 3.85 & 41.38 & 1.09 & 15.16 \\
2007 & 3.98 & 32.28 & 0.82 & 14.99 \\
2008 & 4.28 & 30.09 & 0.66 & \\
\hline
\end{tabular}

Source: U.S. Department of Commerce, International Trade Administration, 1989-2008. 
Table 11

SITC 8415 Imports

\begin{tabular}{lllll}
\hline & China & Hong Kong & Taiwan & India \\
\hline 1989 & 5.97 & 30.79 & 5.35 & 18.15 \\
1990 & 7.74 & 25.60 & 4.92 & 18.47 \\
1991 & 6.30 & 21.77 & 4.52 & 17.82 \\
1992 & 6.80 & 22.32 & 3.88 & 16.09 \\
1993 & 7.18 & 20.10 & 3.20 & 14.12 \\
1994 & 5.13 & 23.18 & 3.84 & 19.04 \\
1995 & 3.78 & 27.27 & 3.86 & 26.35 \\
1996 & 3.46 & 32.36 & 4.17 & 26.18 \\
1997 & 3.67 & 31.69 & 3.75 & 24.56 \\
1998 & 3.01 & 33.53 & 4.00 & 24.71 \\
1999 & 2.86 & 37.44 & 4.26 & 25.13 \\
2000 & 2.93 & 40.09 & 3.98 & 25.49 \\
2001 & 3.12 & 43.36 & 3.93 & 25.34 \\
2002 & 3.06 & 43.08 & 3.05 & 21.53 \\
2003 & 2.83 & 46.42 & 2.91 & 22.67 \\
2004 & 2.67 & 48.58 & 2.75 & 23.44 \\
2005 & 2.75 & 51.49 & 2.57 & 22.21 \\
2006 & 2.91 & 60.62 & 2.20 & 18.94 \\
2007 & 3.59 & 43.30 & 1.88 & 15.49 \\
2008 & 4.04 & 35.63 & 1.84 & 15.09 \\
\hline $504 r:$ & 5.96 & $1989-2008$. & \\
\end{tabular}

Source: U.S. Department of Commerce, International Trade Administration, 1989-2008.

Table 12

SITC 8416 Imports

\begin{tabular}{lllll}
\hline & China & Hong Kong & Taiwan & India \\
\hline 1989 & 17.98 & 369.17 & 5.15 & 0.35 \\
1990 & 17.47 & 329.09 & 4.11 & 0.59 \\
1991 & 15.95 & 284.60 & 2.58 & 0.72 \\
1992 & 12.82 & 292.37 & 3.03 & 0.70 \\
1993 & 11.71 & 218.04 & 2.94 & 0.66 \\
1994 & 9.73 & 265.27 & 3.28 & 1.24 \\
1995 & 9.53 & 334.70 & 3.38 & 7.48 \\
1996 & 8.98 & 18.25 & 3.36 & 6.26 \\
1997 & 8.45 & 13.08 & 3.41 & 11.19 \\
1998 & 6.42 & 16.53 & 3.28 & 19.37 \\
1999 & 6.27 & 15.93 & 2.96 & 23.22 \\
2000 & 6.61 & 15.73 & 3.13 & 19.39 \\
2001 & 6.27 & 15.62 & 2.81 & 22.53 \\
2002 & 5.59 & 15.57 & 2.15 & 18.28 \\
2003 & 5.10 & 15.00 & 1.60 & 20.06 \\
2004 & 5.15 & 9.55 & 0.76 & 19.18 \\
2005 & 5.03 & 3.25 & 0.79 & 18.33 \\
2006 & 5.11 & 2.46 & 0.24 & 14.09 \\
2007 & 5.10 & 2.29 & 0.17 & 9.65 \\
2008 & 5.41 & 1.48 & 0.21 & 7.88 \\
\hline
\end{tabular}

Source: U.S. Department of Commerce, International Trade Administration, 1989-2008. 
Table 13

SITC 8421 Imports

\begin{tabular}{lllll}
\hline & China & Hong Kong & Taiwan & India \\
\hline 1989 & 16.64 & 17.68 & 4.44 & 3.03 \\
1990 & 14.19 & 11.60 & 4.93 & 4.71 \\
1991 & 12.35 & 12.08 & 3.85 & 5.47 \\
1992 & 10.55 & 12.74 & 2.45 & 11.09 \\
1993 & 9.44 & 12.48 & 2.54 & 11.18 \\
1994 & 9.09 & 12.02 & 2.30 & 11.66 \\
1995 & 9.00 & 15.24 & 2.38 & 10.68 \\
1996 & 9.06 & 16.42 & 2.54 & 12.37 \\
1997 & 8.04 & 16.40 & 2.68 & 13.22 \\
1998 & 6.41 & 19.10 & 3.49 & 15.35 \\
1999 & 7.51 & 17.00 & 2.07 & 14.06 \\
2000 & 7.32 & 20.46 & 1.92 & 12.22 \\
2001 & 6.62 & 23.41 & 1.77 & 14.81 \\
2002 & 5.93 & 23.31 & 1.19 & 11.16 \\
2003 & 5.39 & 21.32 & 1.27 & 13.15 \\
2004 & 5.30 & 19.83 & 1.13 & 10.28 \\
2005 & 6.04 & 3.55 & 0.40 & 5.66 \\
2006 & 5.95 & 1.14 & 0.24 & 3.32 \\
2007 & 5.64 & 0.74 & 0.16 & 2.76
\end{tabular}

Source: U.S. Department of Commerce, International Trade Administration, 1989-2008.

Table 14

SITC 8422 Imports

\begin{tabular}{lllll}
\hline & China & Hong Kong & Taiwan & India \\
\hline 1989 & 5.67 & 52.60 & 7.49 & 23.58 \\
1990 & 7.66 & 58.34 & 6.53 & 32.80 \\
1991 & 7.20 & 42.13 & 6.01 & 35.87 \\
1992 & 8.62 & 32.41 & 5.53 & 23.49 \\
1993 & 9.78 & 37.50 & 5.74 & 8.84 \\
1994 & 10.44 & 42.76 & 5.44 & 4.97 \\
1995 & 10.76 & 62.81 & 4.56 & 7.82 \\
1996 & 11.60 & 4.03 & 3.39 & 6.69 \\
1997 & 11.03 & 1.40 & 3.30 & 5.90 \\
1998 & 9.87 & 1.54 & 4.26 & 4.33 \\
1999 & 9.49 & 2.76 & 4.10 & 4.35 \\
2000 & 9.78 & 2.27 & 2.79 & 4.77 \\
2001 & 9.87 & 1.20 & 1.70 & 2.10 \\
2002 & 8.34 & 3.79 & 0.76 & 1.69 \\
2003 & 7.43 & 3.37 & 0.88 & 2.02 \\
2004 & 6.73 & 2.65 & 0.62 & 3.31 \\
2005 & 6.47 & 3.07 & 0.06 & 0.84 \\
2006 & 6.16 & 1.14 & 0.26 & 0.41 \\
2007 & 5.78 & 2.90 & 0.08 & 0.35 \\
2008 & 5.95 & 3.83 & 0.07 & 0.38 \\
\hline
\end{tabular}

Source: U.S. Department of Commerce, International Trade Administration, 1989-2008. 
Table 15

SITC 8423 Imports

\begin{tabular}{lllll}
\hline & China & Hong Kong & Taiwan & India \\
\hline 1989 & 6.37 & 27.87 & 4.01 & 5.90 \\
1990 & 7.43 & 28.10 & 3.74 & 7.75 \\
1991 & 7.14 & 26.57 & 3.31 & 7.08 \\
1992 & 6.29 & 24.30 & 3.40 & 10.16 \\
1993 & 6.99 & 23.70 & 3.14 & 9.68 \\
1994 & 6.42 & 26.25 & 3.43 & 10.45 \\
1995 & 7.20 & 24.39 & 3.60 & 8.26 \\
1996 & 8.26 & 21.83 & 2.88 & 8.91 \\
1997 & 9.12 & 15.98 & 1.89 & 8.08 \\
1998 & 7.78 & 21.14 & 1.69 & 8.10 \\
1999 & 7.62 & 22.59 & 1.31 & 9.64 \\
2000 & 7.14 & 27.03 & 0.87 & 10.94 \\
2001 & 6.44 & 28.79 & 1.52 & 12.27 \\
2002 & 4.90 & 32.16 & 1.22 & 15.19 \\
2003 & 4.45 & 36.95 & 1.27 & 13.84 \\
2004 & 4.00 & 39.32 & 1.73 & 14.11 \\
2005 & 5.64 & 8.31 & 0.42 & 8.65 \\
2006 & 5.64 & 3.22 & 0.16 & 6.87 \\
2007 & 5.41 & 1.81 & 0.25 & 5.38 \\
2008 & 5.61 & 1.23 & 0.20 & 5.28 \\
\hline
\end{tabular}

Source: U.S. Department of Commerce, International Trade Administration, 1989-2008.

Table 16

SITC 8424 Imports

\begin{tabular}{lllll}
\hline & China & Hong Kong & Taiwan & India \\
\hline 1989 & 11.68 & 12.56 & 4.21 & 22.42 \\
1990 & 12.28 & 17.68 & 3.77 & 22.45 \\
1991 & 11.60 & 15.30 & 2.67 & 25.98 \\
1992 & 10.33 & 14.15 & 1.94 & 29.45 \\
1993 & 9.81 & 13.88 & 1.56 & 27.09 \\
1994 & 8.79 & 15.46 & 1.29 & 31.69 \\
1995 & 8.12 & 15.47 & 1.26 & 32.33 \\
1996 & 8.52 & 10.57 & 1.28 & 31.99 \\
1997 & 8.49 & 7.35 & 0.87 & 29.84 \\
1998 & 7.72 & 9.40 & 0.69 & 27.31 \\
1999 & 7.49 & 11.48 & 0.88 & 25.03 \\
2000 & 6.73 & 17.26 & 0.76 & 25.49 \\
2001 & 7.05 & 13.19 & 0.66 & 23.88 \\
2002 & 6.03 & 12.84 & 0.80 & 19.28 \\
2003 & 5.58 & 12.48 & 0.71 & 18.28 \\
2004 & 5.44 & 10.49 & 0.50 & 15.44 \\
2005 & 5.51 & 3.36 & 0.18 & 13.09 \\
2006 & 5.26 & 1.70 & 0.16 & 12.38 \\
2007 & 4.95 & 1.14 & 0.09 & 12.13 \\
2008 & 5.20 & 1.18 & 0.08 & 10.88 \\
\hline S0urce & 0.96 & $1989-2008$ & \\
\hline
\end{tabular}

Source: U.S. Department of Commerce, International Trade Administration, 1989-2008. 
Table 17

SITC 8425 Imports

\begin{tabular}{lllll}
\hline & China & Hong Kong & Taiwan & India \\
\hline 1989 & 9.58 & 44.18 & 4.47 & 20.86 \\
1990 & 9.18 & 50.02 & 4.95 & 25.24 \\
1991 & 7.02 & 60.02 & 5.70 & 20.87 \\
1992 & 6.05 & 59.75 & 4.82 & 21.79 \\
1993 & 6.08 & 62.00 & 3.34 & 32.56 \\
1994 & 5.41 & 66.30 & 3.53 & 37.99 \\
1995 & 5.44 & 70.69 & 3.92 & 30.71 \\
1996 & 5.98 & 19.63 & 3.63 & 27.75 \\
1997 & 6.56 & 14.21 & 3.08 & 27.09 \\
1998 & 6.27 & 16.82 & 3.07 & 21.06 \\
1999 & 5.86 & 22.11 & 2.54 & 21.61 \\
2000 & 5.54 & 21.58 & 1.87 & 28.03 \\
2001 & 5.17 & 27.39 & 2.35 & 24.36 \\
2002 & 4.33 & 29.17 & 1.89 & 21.85 \\
2003 & 4.17 & 25.82 & 2.13 & 22.56 \\
2004 & 4.22 & 25.76 & 2.02 & 18.70 \\
2005 & 4.14 & 6.64 & 0.51 & 28.94 \\
2006 & 4.49 & 2.89 & 0.21 & 22.21 \\
2007 & 4.72 & 1.16 & 0.29 & 15.01 \\
2008 & 4.98 & 1.08 & 0.33 & 13.37 \\
\hline S0urc: & 5.969 & $1989-2008$ &
\end{tabular}

Source: U.S. Department of Commerce, International Trade Administration, 1989-2008.

Tale 18

SITC 8426 Imports

\begin{tabular}{lllll}
\hline & China & Hong Kong & Taiwan & India \\
\hline 1989 & 8.31 & 0.85 & 3.76 & 5.76 \\
1990 & 8.13 & 0.87 & 4.22 & 8.77 \\
1991 & 6.37 & 1.26 & 4.52 & 5.78 \\
1992 & 5.76 & 1.04 & 3.46 & 5.31 \\
1993 & 6.33 & 1.03 & 3.14 & 5.42 \\
1994 & 6.29 & 0.85 & 2.66 & 5.01 \\
1995 & 6.06 & 0.84 & 2.64 & 5.28 \\
1996 & 5.92 & 37.26 & 2.62 & 5.41 \\
1997 & 5.99 & 34.77 & 2.69 & 5.24 \\
1998 & 5.16 & 36.49 & 3.22 & 5.50 \\
1999 & 4.72 & 42.14 & 3.41 & 5.98 \\
2000 & 4.55 & 42.14 & 3.93 & 8.24 \\
2001 & 4.41 & 47.22 & 3.62 & 8.85 \\
2002 & 3.76 & 50.81 & 3.24 & 7.46 \\
2003 & 4.03 & 48.15 & 3.40 & 6.24 \\
2004 & 4.06 & 49.11 & 2.76 & 5.21 \\
2005 & 4.21 & 49.36 & 1.80 & 5.55 \\
2006 & 4.20 & 52.21 & 1.38 & 6.17 \\
2007 & 4.28 & 44.04 & 1.10 & 7.16 \\
2008 & 4.62 & 39.28 & 0.77 & 8.02
\end{tabular}

Source: U.S. Department of Commerce, International Trade Administration, 1989-2008. 
Table 19

SITC 8427 Imports

\begin{tabular}{lllll}
\hline & China & Hong Kong & Taiwan & India \\
\hline 1989 & 10.52 & 0.61 & 1.52 & 29.24 \\
1990 & 11.34 & 0.54 & 1.26 & 33.02 \\
1991 & 10.09 & 0.59 & 1.37 & 30.44 \\
1992 & 8.88 & 0.42 & 0.80 & 29.59 \\
1993 & 10.16 & 0.36 & 0.60 & 22.24 \\
1994 & 8.31 & 0.42 & 0.65 & 27.54 \\
1995 & 7.27 & 0.43 & 0.41 & 29.78 \\
1996 & 7.21 & 20.54 & 0.44 & 31.24 \\
1997 & 7.08 & 17.62 & 0.38 & 29.75 \\
1998 & 5.36 & 23.55 & 0.51 & 30.65 \\
1999 & 4.76 & 27.77 & 0.52 & 32.98 \\
2000 & 4.97 & 25.57 & 0.55 & 34.24 \\
2001 & 5.24 & 25.52 & 0.45 & 31.91 \\
2002 & 3.91 & 25.41 & 0.63 & 32.67 \\
2003 & 3.72 & 28.23 & 0.65 & 29.78 \\
2004 & 3.53 & 30.04 & 0.86 & 27.61 \\
2005 & 4.11 & 12.65 & 0.50 & 26.48 \\
2006 & 4.39 & 4.35 & 0.15 & 23.15 \\
2007 & 4.62 & 2.36 & 0.06 & 16.32 \\
2008 & 4.87 & 2.01 & 0.04 & 15.00 \\
\hline $504 r:$ & 5.96 & $1989-2008$ & \\
\hline
\end{tabular}

Source: U.S. Department of Commerce, International Trade Administration, 1989-2008.

Through a careful analysis of the data obtained, several important observations were made. First, the amount of imports from China, Hong Kong, Taiwan, and India was not significantly affected by the elimination of the quota. Second, there were gradual increases in the imports of some products, during year 2005 in particular, when the ATC quota was fully eliminated. However, the increase did not persist. In 2006, most imports from these leading countries declined. Third, although China became the largest importer of clothing and textile to the United States, statistics showed that the overall amount of imports for half of the products declined gradually. This could be partially due to the economic downfall that started to occur in the United States in the recent years. Fourth, Hong Kong and India's imports showed great fluctuations through the years. While the import of some products increased slightly in response to the ATC quota elimination, others dropped when China rose to become the primary importer. Last, Taiwan did not seem to be affected by the existence or elimination of the ATC quota, since the country was never a major importer of clothing and textile to the United States.

For future studies, it would be interesting to monitor the trade (import and export) patterns between the United States and China in the upcoming years. The economic uncertainties in the United States in recent years might have contributed to a mixed data after the quota removal in 2005 . Thus, to have a better understanding of the wellbeing of international trades in the clothing and textile sectors, it is important to analyze the data for the years ahead.

\section{Conclusion and Implication}

The granting of China's permanent Normal Trade Relations status and the elimination of the clothing and textile quotas have affected international trades between major countries. China, a country with cheap and 
abundant labor, quickly came to power and became one of the primary importers to the United States. Businesses in the United States also benefited from the low-cost import of Chinese-made components, parts, and raw materials, including clothing and textiles (Armington, 1969).

While the outlook for China's economy is positive, it might have some negative implications for the United States. It is true that China's abundant low-cost labor has lowered the cost of production for a variety of goods sold in the United States, which also boosted the consumers' purchasing power. However, low-cost labor and production have also increased the competitiveness of Chinese manufacturers, which resulted in closures of numerous American manufacturing companies. Thus, many have lost their jobs. The clothing and textile quota phase-out further promoted international trade, in particular with China, while increased the unemployment rate in the United States. As more businesses in the United States turn to China for their imports of goods, the United States' economic condition might worsen.

Additional safeguard measures were enacted by the United States in prolonging the quota control for certain products. However, this might only be a temporary solution. Surprisingly, the impact of the elimination of quotas did not significantly affect the quantity of imports to the United States from major exporting regions such as China, Hong Kong, Taiwan, and India. After the full elimination of clothing and textile quotas in 2005, the import of most products began to drop. In part, this shows the ineffectiveness of quota removal in these two sectors. Nevertheless, this decline could be temporary, due partially to the economic downfall in the United States in recent years.

\section{References}

Arce, H. M., \& Taylor, C. T. (1997). The effects of changing U.S. MFN status for China. Weltwirtschaftliches Archiv, 133(4), 737-753.

Armington, P. S. (1969). A theory of demand for products distinguished by place of production. IMF Staff Papers, 16, $159-178$.

China Trade. (2000, July 1). America, p. 3.

Martin, M. (2007). U.S. clothing and textile trade with China and the world: Trends since the end of quotas. Washington DC: Congressional Research Service.

Morrison, W. (2006). China's economic conditions. Washington DC: Congressional Research Service.

The China Threat to World Textile and Apparel Trade. (2002). Washington DC: The American Textile Manufacturers Institute.

Thottam, J., Elegant, S., Kingsbury, K., Ramzy, A., \& Weisskopf, M. (2007, July 9). The growing dangers of the China trade. Time, 28-31.

U.S. Imports for Consumption: Annual Data. (1989-2008). Retrieved November 2, 2010, from United States Department of Commerce, International and Trade Administration: http://dataweb.usitc.gov/scripts/user_set.asp

Yao, S. (2000). Three essays on China’s foreign trade. Ann Arbor: Bell \& Howell Information and Learning Company. 